\title{
NO AGRARIAN REFORM: REVOLUTIE WITHOUT REVOLUTION?
}

\section{Ganjar Razuni, Adilita Pramanti}

Faculty of Social and Political Sciences Universitas Nasional

Email : Ganjarjurnalunas@gmail.com, adilsumsel@yahoo.com

\begin{abstract}
RI's independence is a revolution to form a nation and state with an independent social structure. One of the instruments of de-colonization of the Indonesian people is the Agrarian Revolution. The matter of study in this paper is why, since Sokarno stepped down, the implementation of agrarian reform became half-hearted. This writing method with a literature study through historical, descriptive analysis. The result reveals there has not been a fundamental change in the basic socio-agrarian structure in Indonesia, and people fought for it from 2014 until now.
\end{abstract}

Keywords: Agrarian Reform, Revolution, Agraria, Indonesia

\section{Introduction}

We annually commemorate the National Farmers Day or National Agrarian Day, which is on September 24, or the Anniversary of Law No. 5 of 1960 concerning Basic Agrarian Affairs (UUPA). In President Soekarno's mandate when delivering the Government's Statement as the Proposer of the Agrarian Principles Bill which later became Law No. 5 of 1960 concerning the Basic Agrarian Law (UUPA), President Soekarno stated that: "The Indonesian Revolution Without Agrarian Reform, is the same as the Revolutionary Zonder Revolution (Revolution without Revolution)." Because of the most basic Indonesian revolution, it is; overhaul social inequality, economic structure, and political structure that are feudalistic, dualistic, full of inequality, colonialistic, and even oppressive, which are weak or monopolistic.
Furthermore, there is no exception in the socio-agrarian structure, which is the "basic socio-structural basis" in the life of the peasants and fishermen on the motherland of Indonesia. French Revolution, Enclosure Movement in England, Peasant 'War in Germany, Russian Revolution, Chinese Revolution, Vietnamese Revolution, Bolivian Revolution, Cuban Revolution and revolutions in Latin American countries, Revolution in South Africa, Revolution Namibia, are; the essence of the Agrarian Revolution was to overhaul the social structure of the unequal society, even to overhaul the mentality of the backward-minded people.

In comparison, Agrarian Reform also runs in various parts of the world in societies that are still pre-capitalist or have entered a phase of capitalism, including in pseudo capitalism (ersatz capitalism). Agrarian Reform occurred 
in Africa, among others; in Namibia, South Africa, Zimbabwe; in Asia, among other things; in Japan, China, India, South Korea; in Latin America, among other things; in Venezuela, Bolivia, Mexico; in Europe, elsewhere, in Russia, Italy and Spain. That is Agrarian Reform, occurring in various parts of the world, even though a massive Revolution and Revolutions in the world, in essence, is an Agrarian Revolution (Bernard Limbong; Agrarian Reform; 2013).

\section{Research Question}

According to the research background, the researcher formulates research questions as follows first, is there an agrarian revolution in independent Indonesia? secondly, how are the form and construction of the socioagrarian structure in Indonesia, which makes it difficult for the agrarian revolution in Indonesia?

\section{Methodology}

The researcher conducted this research by utilizing a library method that is equipped with historical, descriptive analysis to explore the depth of meaning of agrarian reform in Indonesia since the first time the Agraria Basic Law No. 5 of 1960 enacted which in its implementation is often "destroyed" by other laws in the field of natural resource management. This study is the result of research using the literature and library methods. Researchers do contextual content analysis from library sources, whether in the form of books, scientific journals, or Indonesian state documents, especially in the form of Indonesian state regulations. From this literature study, it is obtained the form of landscape configuration and construction of the political-agrarian course in Indonesia.

\section{Concept and Theory}

The landscape of the National PoliticoAgrarian course depends heavily on the character of the ruling regime, the power of foreign capital, and the national bourgeoisie. The New Order political system is indeed monolithic, but the economic system is a political-economic road that tends to be liberal. The New Order economic system is an anti-thesis of Bung Karno's self-reliant economic system. While the Pancasila New Order democratic system, in essence, is a continuation, strengthening, deepening, and even towards monolithic. The politicaleconomic and political-economic setting, after the reformation, has positioned RI increasingly right to the path of UltraLiberalism and Individualism in all fields and continues to "Immerse Pancasila" through the "De-Ideologizing Process of Pancasila." President Jokowi's leadership has a mission and historical duty to return the country to the Pancasila REL. This is the direction that must be taken by this country, not least in the field of Spatial Planning and National Arrangement. Therefore, any Agrarian Minister must also inspire the national mission, vision, nature, contour, culture, 
and political-agrarian structure as the basis of life for the Indonesian marhaen; Farmers and Fishermen. The Minister of Agraria presumably must side with the direction and new path of the National Political-Agrarian by Nawacita and Tri Sakti Bung Karno as a way back to Pancasila.

\section{Result and Discussion}

Forms of Agrarian Reform and Agrarian Politics (1945-1965)

In Indonesia, to take advantage of the agrarian reform before the stage of industrialization, UUPA No. 5 of 1960, which turned out to be made in quite a long time, namely, from 1948 until it completed on September 24, 1960, it became 12 yearsstarted by the Yogya Committee on May 21, 1948, with its Chairman Mr. Sarimin Reksodihardjo. Then it was continued by the Jakarta Committee, March 19, 1951. In this era, the Constitution or our Constitution was the Provisional Constitution of 1950-1959 with liberalism and individualism orientation. This team leader, it is still Mr. Sarimin, and the Deputy Chairperson are Sadjarwo. In connection with the determination of $\mathrm{Mr}$. Sarimin as the Governor of Nusa Tenggara, then Mr. Sarimin, as Chair of the Jakarta Committee, was replaced by Singgih Praptodihardjo. Because the leadership of this committee often gets individual assignments from the President outside of the committee's technical duties, there are not many results that can be achieved by the
Jakarta Committee. Then with Presidential Decree No. 55/1955 on March 29, the Ministry of Agriculture was formed for the first time, and then a new committee was formed, and the old committee was dissolved, and a new committee was formed; Soewahjo Sumodilogo Committee. Through some changes, Soewahjo Committee's work was proposed by the Minister of Agraria to the Council of Ministers as Soenaryo's Draft. Then the Bill was proposed by the Government to the Indonesian Parliament with Ampres on April 24, 1958.

After having a tricky discussion in the Indonesian Parliament chaired by an Ad Hoc Chairman A. M. Tambunan and receiving various inputs from Prof. Notonegoro (UGM) and Prof. Wirjono Prodjodikoro (Chief Justice of the Supreme Court), the Soenarjo draft was withdrawn by the government on May 23, 1960, due to the re-enactment of the 1945 Constitution following the Presidential Decree of July 5, 1959. After the bill was adjusted to the spirit of the 1945 Constitution and the RI Political Manifesto, namely; President Soekarno's speech on August 17, 1959, the text was subsequently submitted as an Agrarian Bill by the Minister of Agrarian Sadjarwo which had been approved by a Cabinet plenary meeting and with Ampres on August 1, 1960, submitted as the Basic Agrarian Bill to the DPR-GR. The building of the conception that underlies it, Sadjarwo's Draft explicitly uses Customary Law as its basis. Thus the unanimous vote of the DPR 
GR known by KH. Zainul Arifin (NU), on September 14, 1960, approved the Sadjarwo Ke II Bill unanimously after receiving input from customary and religious law experts. Then the bill, which was approved by the DPR GR unanimously on Saturday, September 24, 1960, was passed/promulgated by President Soekarno into Law No. 5 of 1960 concerning Basic Agrarian Affairs (UUPA) which came to be known as National Peasant Day.

We should remember that the outline of the GR DPR's composition, which approved the Basic Agrarian Bill. It consists of; first, Political Party Groups based on the proportionality of the 1955 Election Results with a total of 130 seats consisting of seats; PNI 44 seats; NU 36 discussion; PKI 30 seats; PSII 5 seats; Parkindo 6 seats; Catholic Party 5 seats; PERTI 2 seats; Murba 1 chair and; Partindo 1 seat; Second, the Group of Work Groups that were appointed numbered 150 people consisting of; ABRI 35 seats (AD 15 seats, AL 7 seats, AU 7 seats, POLRI 5 seats, and OPD / OPR 1 seat); 25-seat farmer; Labor 25 seats; Alim Ulama 31 seats (Islam 24 seats; Protestant 3 seats; Catholic 2 seats; Hindu Buda 2 seats); Youth 8 seats; 8 seat woman; Scholar of 5 chairs; 3-seat cooperative; National Businessman 2 seats; Class of 45 , 2 seats; Veterans 2; Artist 2; Reporter 2; and one representative from West Irian. The total number of DPR members is 281 seats.

Therefore factually, it seems unreasonable for the Stigmatization of the LoGA to be a "Law that smells of PKI," as seen during the New Order era, even in this Reformation era, there is still reluctance to implement the LoGA due to the PKI Stigma. More than that, the LoGA is blocked or "torpedoed" with various laws in the field of management of other natural resources with individualism and liberalism, such as the PMA Law, Minerba Law, Forestry Law, Plantation Law with various PP UUPA that also "spay" the LoGA itself. It all happened after the resignation of President Soekarno in 1967 and after the National Tragedy of 30 September 1965 as well as various political events and massacres that occurred after 1965 to 1969. Besides UUPA No. 5 of 1960 , related to agrarian reform, there is also Law No. 56 Prp of 1960 concerning Land Reform and Law No. No. 2 of 1960 concerning Production Sharing Agreements and Law No. 16 of 1964 concerning Fishery Product Sharing. All of these laws have their roots, of course to the LoGA which has the spirit of Indonesian socialism, namely Pancasila which is based on communalism and not individualism or liberalism and is also strengthened by the USDEK MANIPOL (Political Manifesto, 1945 Constitution, Indonesian Socialism, Guided Democracy, Guided Economy and Indonesian Personality).

Indeed, in that era, apart from its shortterm political interests, the PKI "fervently" fought for the implementation of concrete land reform in the countryside, including the coastal regions. It can be seen from the grouping in the discussion of the BAL Bill in 
DPR GR. It covers the Radical Group, which are members of PNI, PKI, Murba, Socialist Party, and IPKI, who proposed a long-term land redistribution program based on a single principle. It states that those who work the land are entitled to own the land. Second, the Conservative Group consists of mostly representatives of Islamic groups and parties who oppose restrictions on land ownership and; Third, the Moderate Group, which included President Soekarno and Minister of Agrarian Sadjarwo. This group accepts the opinion of radical groups but emphasizes that change must be gradual, where the first stage is to focus on setting maximum land area limits and minimum land ownership limits (quoted from, Arie Sakanti Hutagalung; Land Redistribution Program in Indonesia; 1985).

Apart from the PKI's short-term political interests, it related to the implementation of the Land Reform. The PKI Central Committee had conducted agrarian research in rural and coastal areas ranging from Bogor, Cianjur, Sukabumi, Lebak, Pandeglang, Sumedang, Majalangka, Cirebon, Indramayu, Karawang in 1962-1963. It results in the conclusion that there are things that make the most impoverished farmers and fishermen always in what is called the Seven Village Devils, namely, Evil Landlord; Loan shark; Bonded Bonders; Evil Middlemen; Village Bandits; Capitalist-Bureaucrat; Evil Ruler. While the forms of exploitation of farmers and fishers in rural and coastal areas are; Landlord's Monopoly on Land; Land Lease in the Form of Land Products; Land Lease in the Form of Work on Land of Landlords; Debts That Strangle Farmers and Fishermen. (Rex Mortimer; PKI and Agrarian Reform 19601965). It turns out that at least, as a large part of this phenomenon, there are still in the villages and villages to date, which means that there has not been any structural social and political, economic change in the villages and coastal areas. Some of the elements of the Seven Devils of the Village are still "haunted" to this day.

The state's attention to the national agrarian problem, in addition to the struggle for the existence of the LoGA, then from 1150 to the end of President Soekarno's era, there was always the Ministry of Agrarian Affairs and, even from the President of the Republic of Indonesia to the Village Head as Chair of the Land Reform Committee according to his level, proves how high political -committed of which he all runs Agrarian Reform.

\section{Political-Agrarian Construction of the New Order Era (1967-1998) and the Reformation Era of Indonesia (1998-2014 and 2014-present)}

Since the beginning of the New Order and throughout the New Order era, there has never been an agrarian ministry, and agrarian affairs have only been placed in the Directorate General of Agraria under the Ministry of Home Affairs of the Republic of Indonesia. It was only during the Development Cabinet VI, VII, and the Development Reform Cabinet 
that the Ministry of Agriculture was formed. However, then since the 1999 Reform, there is no Ministry of Agrarian anymore, there is only one body, namely, the National Land Agency, which is undoubtedly not a Cabinet Member. It was only during the Jokowi-JK administration, reviving the Ministry of Agriculture / BPN as the implementation of Nawacita in the spirit of the Bung Sakno Tri Sakti (Sovereign in Politics; Self-Reliance in Economics and; Personality in Culture) as a way back on the Pancasila REL. Even though the social structure of society and the nation has not changed, but at least a new leader has laid an "ideological path" to return to the Pancasila REL. Be careful and do not forget, that for foreign powers, if a nation wants to control the people of another country, then its food is controlled, and if it wants to control its country, its energy is controlled. Therefore, President Jokowi's government needs to form a special team consisting of all relevant agencies and universities and practitioners, for example, the Agrarian Reform Consortium to conduct Harmonization and Synchronization based on UUPA No. 5 of 1960, Tri Sakti Bung Karno and Nawacita overall regulations; Laws and all forms of regulation which become the government's authority regarding the management of natural resources. Therefore, the performance, stability, and sustainability of the administration of President Jokowi need to continue to be managed optimally and adequately prepare for the better implementation of Nawacita II for post-20192024. Thus, the Omnibus Law acquiescence is a step forward to undertake various harmonization or amendments to laws and regulations which impede investment and do not favor the interests of the people to achieve the ideals of the Indonesian Revolution of Independence.

\section{Conclusion}

Based on the aforementioned results of research and discussion, the conclusions of this paper conclude that there are five crucial things in the discussion about the form and construction of social-agrarian structures that occur in Indonesia and become a description of the conditions of agrarian politics from 1945-2019 as well as being a challenge or obstacle to the agrarian movement in Indonesia, are:

1. The political-agrarian direction in the 1945-1965 era which was very ideological and decisive, in the process of decolonization of the Indonesian people which was strengthened to build the original form and construction of a socio-agrarian structure with a socialistic character for the sake of feudalism, the national bourgeoisie, and alternative bourgeoisie also with the culmination of the UUPA 1960 on September 24, 1960;

2. However, since the New Order period 1967-1998 there was a liberalization process in the field of agrarian, through 
political-agrarian

characteristics

of liberalism-capitalistic, and stigmatization of the BAL 1960 as a result of the PKI, even to those who were in agrarian problems, as well as in the field of agriculture and plantations are easily suspected as part of PKI elements or more easily "left";

3. Since the Reformation era of 19982014 there have been "ups and downs" of liberalism and capitalism, even some ultra-liberalism in the political-agrarian dynamics, which are related to the 1960 BAL, the approval of the DPR and the President concerned, and in the negotiations of the BAL "under attack" or degraded by other laws, including; Plantation Law, PMA Law, Forestry Law and so on, so that the ideals of the 1960 BAL are farther away;

4. Towards the 2014-2019 era, there was an effort to re-establish the so-called Agrarian Reform as part of efforts to realize social justice in the political-agrarian field, but it has only proceeded on a symbolic level, and has not had research roots, for example; only limited to the aspect of land certification, but has not yet moved to changes in the socio-agrarian structure with fundamental interactions;

5. Therefore, policy reorientation needs to be done so that the state's policy and politics and agrarian return to the initial ideals of the independence of the Republic of Indonesia, which are inseparable from its socialistic and social character. Anti-feudalism system and the conventional system which can always change the basics in the socioagrarian structure.

\section{Reference}

Aidit, DN, 2002, Revolusi Indonesia, Cetakan Pertama, Oesaha Terbitan Raja Minyak, Yogyakarta.

, 1962, Sosialisme Indonesia dan

Sjarat-Sjaratnya, Cetakan Pertama, Akademi Ilmu Sosial Aliarcham, Jakarta.

Achdian, Andi, 2009, Tanah Bagi Yang Tak Bertanah: Land Reform Pada Masa Demokrasi Terpimpin 1960-1965, Cetakan Pertama, KEKAL Press, Bogor, Jawa Barat.

Apridar, 2017, Teori Ekonomi: Sejarah dan Perkembangannya, Cetakan Pertama, Penerbit Graha Ilmu, Jakarta.

Harsono, Budi, 1999, Hukum Agraria

Indonesia: Sejarah Pembentukan

Undang- Undang Pokok Agraria,

Isi Dan Pelaksanaannya, Cetakan

Kesembilan, Penerbit Djambatan, Jakarta.

Hutagalung, Suakanti, Arie, 1985, Program

Redistribusi Tanah Di Indonesia:

Suatu Sarana Ke Arah Pemecahan Masalah Penguasaan Tanah dan Pemilikan Tanah, Cetakan Pertama, Rajawali Press, Jakarta. 
Limbong, Bernard, 2012, Reforma Agraria, Tjondronegoro, S.M.P dan Wiradi, Gunawan Cetakan Pertama, Penerbit Margaretha (Penyunting), 1984, Dua Abad Pustaka, Jakarta.

Penguasaan Tanah, PT Gramedia, Rachman, Fauzi, Noer, 2012, Land Reform Jakarta.

Dari Masa Ke Masa, Cetakan Pertama, Parlindungan, AP, "Politik dan Hukum Agraria Penerbit Tanah Arr Beta, Kota Depok, Jawa Barat.

Di Zaman Orde Baru”, Prisma, No. 4 tahun 1989.

2017, Petani dan Penguasa Tanah:

MPR RI, Ketetapan MPR No. IX/ MPR/ Dinamika Perjalanan Politik Agraria Indonesia, Cetakan Pertama, Insists Press, Yogyakarta.

Razuni, Ganjar, 2014, Jombang Potret 2001 tentang Pembaruan Agraria dan Pengelolaan Sumber Daya Alam.

RI, Undang-Undang Dasar Negara Republik Indonesia. Transformasi Politik Agraria. Cetakan Pertama Adil Indonesia RI, Undang-Undang No. 5 tahun 1960 Institute, Jakarta. tentang Peraturan Dasar Pokok-Pokok Agraria. 